\title{
THE APPLICATION OF ONLINE SOCIAL MEDIA IN A THAI TUTORIAL SCHOOL: A CASE STUDY OF ECHO AVIATION, THAILAND
} ANON UA-UMAKUL \& ORRAPHATKAN CHAIWATCHATUPHON

Ed.D. in Educational Studies, Faculty of Education, Rangsit University, Patumthani, Thailand

This research aimed to study the using of online social media in the Echo Aviation Tutorial School Thailand, and to assess the opinion of students, about using online social media in this school. Purposive sampling was employed. The participants were Executive School Director and the twenty students, who enrolled in English for Communication. There were two research instruments in this study: 1) the structured interview form, and 2) the opinion assessment form. The content validity was examined by three experts in the area of educational studies. The IOC value was between 0.67 1.00. The data analysis was divided into two parts: 1) qualitative data were analyzed by content analysis, and 2) quantitative data were analyzed by arithmetic mean and standard deviation. The results were shown as follows:

1) The benefits of using online social media in this school were revealed in three aspects: 1.1) it was used for notifying the school information conveniently, rapidly, and saved cost for school administration, 1.2) it can promote the students' class participation in real time continually, and 1.3) it increased the students' learning achievement scores by their potential.

2) The assessment of students' opinion was in the high level $(x \overline{=} .29, S D=0.65)$.

There were two recommendations of this study. The school ought to explain the using of all functions in online social media to students in more details and compare the using of online social media proper with the school for instruction.

KEYWORDS: Online Social Media for Administration, Thai Tutorial school \& School Administration
\end{abstract}

Received: Nov 20, 2017; Accepted: Dec 05, 2017; Published: Dec 12, 2017; Paper Id.: IJESRDEC201715

\section{INTRODUCTION}

\section{Background of the Study}

To develop Thailand to steadiness, wealth and sustainability in the nearest future, the educational development process must be done systematically, in both short term and long term. Especially, human development, it is very important and need to be prepared for changing of technology in twenty-first century. Thus, the using of information technology as tools for educational development have been prescribed in Education Development Plan of the Ministry of Education No. 12 B. E. 2560-2564 and used for supporting educational administration, educational innovation development, and instruction in both formal and non-formal education. For online social media, it has been studied and done research for recent years. The findings can be supported to response the educational goals (Ministry of Education, 2017, pp. 10-17; Pholpasri, 2011; Somboontanakorn, Chaowaneeranat and Kanyacome 2016, pp. 115-123; Sorana, 2011). 
In addition, the National Education Act specifies the criteria, for school administration in four aspects: academics, budget, human resources management, general school administration; including the tutorial school administration which is non-formal education. So, the aspect of educational administration appears in National Education Act is divided into seven parts: 1) the curriculum and instruction development, 2) buildings, maintenance, and environment, 3) student affairs, admissions, and registration, 4) PR, and market promotion, 5) school administration, 6) human resource development, and 7) relationship between school and community (Aeimsirirak, Sumettikul, and Sinlarat, 2013, pp.198-199).

To response the above direction of educational development in Thailand in macro scale, the tutorial schools usually use information technology and online social media, for school administration in part of curriculum and instruction development which trends to expand continually. There are many ways to use information technology and social media for supporting students learn. For example, the teachers can integrate the social media in class which gives the students the opportunity to review their lessons or contents through the Internet. Besides, the teachers use the online social media for communicating to their students and sharing the opinions together. Therefore, the using of social media is the one way to support the learning and teaching in the schools (Pholpasri, 2011; Sorana, 2011).

At the present, the current of social network make people change their live greatly. Especially, in education aspect, the social media originate the educational change in 4.0 eras considerably (Manager Online, 2011). The meaning of social network in Thailand is prescribed by Office of the Royal Society (2015) that, the groups of people who communicate by social media to transfer and share information or make the interested activities together, whereas the meaning of social media is defined that the electronics media used, for sharing the opinion by the Internet (Aroonpiboon, 2012).

The using of social media in educational administration, classroom management, and instruction can assist the educational administrators, teachers and students learn together by using operational system in smart phone, or tablet. The contents in each subject area which consist of text, picture, sound, video and others can be integrated in class and help the students assimilate the body of knowledge and skills better (Honey church and Ahmed, 2016; Sorana, 2011). According to the above background of the study, the researchers are interested in the study of the application of online social media in a Thai tutorial school and defined the research objectives, in two aspects presented in the next section.

\section{Research Objectives}

The research objectives are showed as below:

- To study the using of online social media in the Echo Aviation Tutorial School, Thailand.

- To assess the opinion of students about using online social media in this school.

\section{Research Questions}

There are two research questions of this study presented as below:

- What are the results of using online social media in the Echo Aviation Tutorial School, Thailand?

- What are the students' opinions about using online social media in this school? 


\section{Scopes of the Study}

The scopes of this study are determined as follows:

- The mixed method is used in this research. The qualitative data is collected by Executive School Director, a key informant to answer the first research question, and to construct the students' opinion assessment form and use this form for gathering the quantitative data (Buasonte, 2011, pp.8-9).

- $\quad$ The timing to collect data is during September -November 2017.

\section{Conceptual Framework}

The conceptual framework is illustrated in the diagram as below

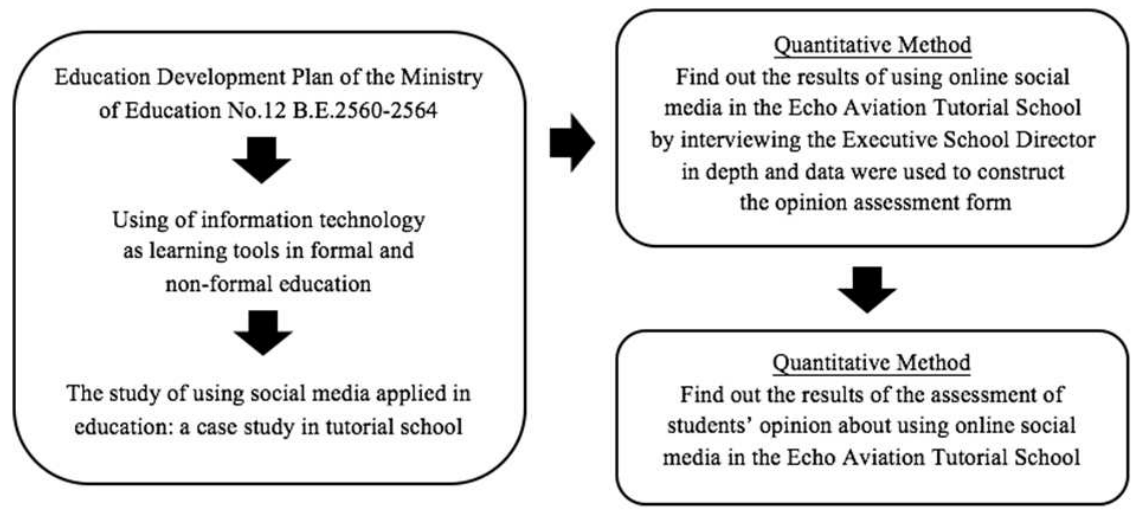

Figure 1: The Conceptual Framework

\section{METHODS}

\section{Participants of the Study}

The participants of the study are selected by purposive sampling. They are twenty students who enrolled in English for Communication course and Executive School Director of the Echo Aviation School, Bang Sue Bangkok, Thailand.

\section{The Construction of Research Instruments}

There are two research instruments in this study a structured interview form, and the assessment form of the students' opinion about using online social media in the Echo Aviation School which is applied from the Pholpasri's research (Pholpasri, 2011, p. 12). The construction of them is presented as below:

- Study on the Education Development Plan of the Ministry of Education No. 12 B.E. 2560-2564 and related document

- Design the research instruments structured interview form with five items and the content validity is examined by three experts in the area of educational studies with index of item-objective congruence or IOC which has to be more than 0.50 . 
- Interview Executive School Director and data are used to design the assessment of students' opinion form about using online social media in this school.

- Construct the assessment of students' opinion form about using online social media and examined the content validity by three experts in the area of educational studies.

- $\quad$ Try out the form and edit language used.

- $\quad$ Survey the students' opinion and analyze data.

\section{Data Collection and Analysis}

The data of study was collected from September to November, 2017. The process of data collection and analysis presented in more details as below:

- The researchers contacted to Mr. Poranix Tangthongkum, who has worked as Executive School Director of Echo Aviation, Bang Sue, Bangkok, Thailand and asked for the permission for collecting data during $2-5$ September, 2017.

- The researchers appointed Executive School Director to interview in depth, about using online social media in school and data were analyzed, by content analysis to construct the students' opinion assessment form. The analyzed data were described and presented on Table.

- The students' opinion assessment form was used and analyzed, with arithmetic mean $(\bar{x})$ and standard deviation (SD).

- $\quad$ The analyzed data were interpreted, with five rating scales (Best, 1977).

$$
\begin{array}{cccccc}
\bar{x}=4.50-5.00 & \text { means } & \text { Highest Level } & \bar{x}=3.50-4.49 & \text { means } & \text { High Level } \\
\bar{x}=2.50-3.49 & \text { means } & \text { Moderate Level } & \bar{x}=1.50-2.49 \text { means } & \text { Low Level } \\
& \bar{x}=1.00-1.49 \text { means } & \text { Lowest Level }
\end{array}
$$

\section{THE RESULTSAND DISCUSSIONS}

The results of this study are presented in two parts:

- The result of interview in depth to answer the research question 1 and

- The result of students' opinion assessment to answer the research question 2. They are shown as follows: 
Table 1: Results of Using Online Social Media in Echo Aviation Tutorial School

\section{by Interviewing Executive School Director}

\begin{tabular}{|c|c|}
\hline Questions & $\begin{array}{ll} & \text { Findings } \\
\end{array}$ \\
\hline $\begin{array}{l}\text { 1. Have you ever used the online } \\
\text { social media in your school? How? }\end{array}$ & $\begin{array}{l}\text { The online social media have been used in school since the school } \\
\text { opened. For example, the teacher team has used the chat group to consult } \\
\text { students, posted the video clips which the students can review the } \\
\text { lessons on the Internet, and informed the news of school to students, } \\
\text { parents, and other interested persons. }\end{array}$ \\
\hline $\begin{array}{l}\text { 2. Why have you chosen the online } \\
\text { social media to administrate your } \\
\text { school? }\end{array}$ & $\begin{array}{l}\text { At present, digital news which is broadcasted conveniently, fast, and } \\
\text { accurately is used for communicating and giving feedbacks in real time. } \\
\text { Hence, the school needs to use an online social media for academic } \\
\text { administration, especially classroom management. The online social } \\
\text { media has been used to support our students participate in class and } \\
\text { receive the high learning achievement scores based on their potential. }\end{array}$ \\
\hline $\begin{array}{l}\text { 3. What are the strong points of using } \\
\text { online social media for classroom } \\
\text { management? }\end{array}$ & $\begin{array}{l}\text { There are four strong points of using online social media: 1) The school } \\
\text { can inform the news and contents which student learned in class } \\
\text { conveniently, fast, and accurately. Besides, it saves costs for school } \\
\text { administration such as printing a document. 2) The online social media } \\
\text { can make the interaction between teacher and student. The students dare } \\
\text { to ask the questions, discuss about interested academic issues, and } \\
\text { sharing idea with their classmate more than they do in classroom. 3) The } \\
\text { online social media can make the warm learning atmosphere in class. 4) } \\
\text { The online social media can support the students use the smart phone } \\
\text { worthily. }\end{array}$ \\
\hline \multirow[t]{3}{*}{$\begin{array}{l}\text { 4. How does the online social media } \\
\text { be used in classroom? }\end{array}$} & $\begin{array}{l}\text { All registered students have smart phones, so the online social media is } \\
\text { used very easily and high efficiently to level up their learning } \\
\text { achievement scores. The ways to use them are as follows: } \\
\text { 1) To inform the news about new lessons for next class. } \\
\text { 2) To review previous lessons by recording clip videos. } \\
\text { 3) To give the students the opportunity for asking questions by } \\
\text { online live streaming. }\end{array}$ \\
\hline & $\begin{array}{l}\text { T) To use for discussion between students and teachers or group } \\
\text { of student by posting the interested issued on weblog or chatting with } \\
\text { application. }\end{array}$ \\
\hline & 5) To share the data from other learning resources. \\
\hline $\begin{array}{l}\text { 5. What is the benefits for using } \\
\text { online social media in Echo Aviation } \\
\text { Tutorial School in administrative } \\
\text { aspect? }\end{array}$ & $\begin{array}{l}\text { There are some benefits for using online social media in this school } \\
\text { shown as follows: } \\
\text { 1) The school can manage the classroom easily. } \\
\text { 2) The school can manage the news for the students who want to } \\
\text { register in school and their parent. } \\
\text { 3) The school can manage the budget for academic } \\
\text { administration conveniently and economically. }\end{array}$ \\
\hline
\end{tabular}

Remark: Adapted questions from Pholpasri, 2011, p.12

The findings from the qualitative data in Table 1 were used, for constructing the students' opinion form. The quantitative data from this instrument were analyzed and presented on Table 2. 
Table 2: The Results of Students' Opinion about Using Online Social Media in

Echo Aviation Tutorial School $(\mathbf{N}=\mathbf{2 0})$

\begin{tabular}{|c|c|c|c|c|c|c|c|c|c|}
\hline \multirow{2}{*}{$\begin{array}{l}\text { Participant } \\
\text { Number }\end{array}$} & \multicolumn{6}{|c|}{ Items } & \multirow{2}{*}{$\bar{x}$} & \multirow{2}{*}{ S.D. } & \multirow{2}{*}{ Data Interpretation } \\
\hline & 1 & 2 & 3 & 4 & 5 & 6 & & & \\
\hline 1 & 5 & 5 & 4 & 4 & 5 & 4 & 4.50 & 0.55 & Highest \\
\hline 2 & 4 & 5 & 5 & 4 & 4 & 4 & 4.33 & 0.52 & High \\
\hline 3 & 5 & 5 & 5 & 4 & 4 & 4 & 4.50 & 0.55 & Highest \\
\hline 4 & 3 & 4 & 3 & 4 & 4 & 3 & 3.50 & 0.55 & High \\
\hline 5 & 5 & 5 & 4 & 4 & 5 & 3 & 4.33 & 0.82 & High \\
\hline 6 & 5 & 5 & 5 & 5 & 5 & 5 & 5.00 & 0.00 & Highest \\
\hline 7 & 4 & 4 & 3 & 3 & 4 & 4 & 3.67 & 0.52 & High \\
\hline 8 & 4 & 4 & 4 & 4 & 4 & 5 & 4.17 & 0.41 & High \\
\hline 9 & 5 & 4 & 4 & 3 & 4 & 4 & 4.00 & 0.63 & High \\
\hline 10 & 5 & 4 & 4 & 3 & 4 & 5 & 4.17 & 0.75 & High \\
\hline 11 & 5 & 4 & 3 & 5 & 5 & 5 & 4.50 & 0.84 & Highest \\
\hline 12 & 5 & 5 & 4 & 5 & 5 & 5 & 4.83 & 0.41 & Highest \\
\hline 13 & 5 & 5 & 4 & 4 & 5 & 4 & 4.50 & 0.55 & Highest \\
\hline 14 & 5 & 5 & 5 & 5 & 5 & 5 & 5.00 & 0.00 & Highest \\
\hline 15 & 4 & 4 & 4 & 4 & 4 & 4 & 4.00 & 0.00 & High \\
\hline 16 & 4 & 5 & 4 & 4 & 4 & 4 & 4.17 & 0.41 & High \\
\hline 17 & 4 & 5 & 4 & 3 & 4 & 4 & 4.00 & 0.63 & High \\
\hline 18 & 4 & 5 & 4 & 5 & 5 & 5 & 4.67 & 0.52 & Highest \\
\hline 19 & 5 & 4 & 4 & 4 & 4 & 5 & 4.33 & 0.52 & High \\
\hline 20 & 5 & 4 & 3 & 4 & 3 & 3 & 3.67 & 0.82 & High \\
\hline \multicolumn{7}{|c|}{ Total } & 4.29 & 0.65 & High \\
\hline
\end{tabular}

The arithmetic mean and standard deviation are used to analyze the students' opinion scores about using online social media. The results are found that the students' opinion is the high level with $\bar{x}=4.29$ and S.D. $=0.65$.

The findings of this study reveal that the advantages of using social media in this school were three points. Firstly, it can inform the news to students easily and save a cost to administrate. Secondly, it assists the students participate in classroom quickly and uses in real time. Lastly, it helps the student improve their learning based on the students' potential.

Based on the findings, the online social media is proper for the current education in information technology 4.0 era because it helps the students assess the information easily and fast. Many multimedia which consists of texts, pictures, sounds, and videos can stimulate their learning through using their smart phone. Besides, the online social media help a school administrator manage the school works effectively because the information is broadcasted widely, economically and quickly through the Internet. Moreover, the real-time interaction between the school officers and students or parents promptly occur without meeting face to face. The school officers can give the correct information to contactors whereas the students or parents can ask for the true information with them directly.

\section{CONCLUSIONS}

In conclusion, the using online social media can be used for school administration in many ways, especially academic administration, and budget administration. To increase the efficiency of school administration, the explanation of the using all functions in online social media to students or contactors in more details need to do because it can help the school administrator manage the school easily and rapidly. For example, the students who want to know any information about the tutorial fee can ask the school officers directly by using proper function of online social media such as chatting program, or live streaming, and they can pay the tutorial fee systematically and fast while the school officer can recheck 
the data through the Internet system. Furthermore, the comparison about the using of online social media properly with administrative duties need to be studies in the future work.

\section{ACKNOWLEDGEMENTS}

We would like to thank Mr. Poranix Tangthongkum, Executive School Director of Echo Aviation Tutorial School, Bang Sue, Bangkok in Thailand, who permit the researchers to interview in depth. We also thank the students, who devote their time for this surveying.

\section{REFERENCES}

1. Aeimsirirak, A., Sumettikul, P. and Sinlarat, P. (2013). Management Strategies of Tutorial Schools for the Promotion of Corporate Social Responsibility.EAU Heritage Journal: Social Science and Humanities. 3(2), 198-199.

2. Aroonpiboon, B. (2012). Social Media andSocial Network. Retrieved from http://www.thailibrary.in.th/2012/01/10/socialmedia-social-network/

3. Best, J. W. (1977). Research in Education( $3^{\text {rd }}$ ed.).Englewood Cliffs. New Jersey: Prentice Hall, Inc.

4. Buasonte, R. (2011). Mixed Methods in Educational Research. Silpakorn Educational Research Journal, 2(2), 7-20.

5. Honeychurch, S. and Ahmed, S. (2016). Using Social Media to Promote Deep Learning and Increase Student Engagement. Retrieved fromhttp://eprints.gla.ac.uk/132368/1/132368.pdf

6. Tsai-Feng Cheng et al., Construction of Assessing Indicators of Evaluation Benefits for Senior High Schools Explored on Focus Group, International Journal of Educational Science and Research (IJESR), Volume 7, Issue 1, January - February 2017, pp. 7-14

7. Manager Online. (2011). Research on Social Network. Retrieved fromhttp://www.manager.co.th/iBizChannel/ViewNews.aspx?NewsID=9540000041424

8. Ministry of Education. (2017). Education Development Plan of the Ministry of Education No. 12 B.E. 2560-2564. pp. 10-17. Retrieved from http://www.moe.go.th/moe/th/news/detail.php?NewsID=47194\&Key=news20

9. Ariel P. Tuazon et al., School Practices in Parental Involvement, Its Expected Results \& Barriers in Public Secondary Schools, International Journal of Educational Science and Research (IJESR), Volume 6, Issue 1, January - February 2016, pp. 59-78

10. Office of the Royal Society. (2015). The meaning of Social Media and Social Network. Retrieved from http://www.royin.go.th/?page_id=9522/

11. Pholpasri, G. (2011). Online Social Network in Thai Higher Education: A Study of Facebook Integrated Classroom Activities. Retrieved fromhttp://lib.dtc.ac.th/research/Gunn.pdf

12. Somboontanakorn, P., Chaowaneeranat, W. and Kanyacome, S. (2016). Behavior of Using Social Media Online to Support the Instruction: The Case Study of Second Year Students at the Level of Certificate of Vocational Education Studying the Course in Using Graphics Program, Department of Business Computer, SawangDaen Din Industrial and Community Education. Nakhon Phanom University Journal, 6 (1), 115-123.

13. Sorana, W. (2011). Integration of teaching and learning by Social Network. Retrieved from http://www.social.rbru.ac.th/pageNew/research/budget\%20year\%2054/11.Integration\%20of\%20teaching\%20and\%20learnin g\%20by\%20Social\%20Network.pdf 


\section{APPENDIX}

The Assessment Form of the Using Online Social Media in Echo Aviation Tutorial School

Date \& Time

\begin{tabular}{|c|c|c|c|c|c|c|}
\hline \multirow[t]{2}{*}{ Item } & \multirow[t]{2}{*}{ List of assessment } & \multicolumn{4}{|c|}{$\begin{array}{l}\text { Strongly } \\
\text { Disagree }\end{array}$} & $\begin{array}{l}\text { Strongly } \\
\text { Agree }\end{array}$ \\
\hline & & 1 & 2 & 3 & 4 & 5 \\
\hline 1 & The online social media can be used to inform the news about lessons. & & & & & \\
\hline 2 & The online social media can be used to review the previous lessons. & & & & & \\
\hline 3 & $\begin{array}{l}\text { The online social media give you the opportunity for asking or } \\
\text { consulting about your study at once. }\end{array}$ & & & & & \\
\hline 4 & $\begin{array}{l}\text { The online social media can be used for discussion between you and } \\
\text { your teachers. }\end{array}$ & & & & & \\
\hline 5 & $\begin{array}{l}\text { The online social media can be used for discussion between you and } \\
\text { your friends. }\end{array}$ & & & & & \\
\hline 6 & The online social media can be used to generate your co-creation. & & & & & \\
\hline
\end{tabular}

Source:Pholpasri, 2011, p.12 